\title{
Will the Real Pro-Family Contestant Please Stand Up? Another Look at Families and Pastoral Care
}

\author{
Bonnie J. Miller-McLemore, Ph.D. \\ Associate Professor of Religıon, Personality and Culture \\ Chicago Theological Seminary \\ 5757 South University Avenue \\ Chicago, IL 60637-9990
}

Claıms that the contemporary emphasis on the family-often heralded as an exclusive concern of the political and relıgıous right-must not be allowed ownership by any one actor or segment involved in the current culture war dealing with family values. Proposes that at the heart of the family values project is not, as it is often framed, the issues of individualism, divorce, single-mothers, pregnant teens, neglected or problem chıldren, but rather the truly diffıcult problem of establıshıng and maintaınıng genuınely democratıc famıly forms and dynamics. Argues that pastoral caregivers need to reclaim an appropriate space in this contested terrain of THE FAMILY with the pastoral care, counseling, and education's usual commitment to a systemic and compassionate understanding of such complex issues.

$\mathbf{M}$

ore than a decade ago, in an essay written just prior to the November 1980 election of Ronald Reagan and the beginning of twelve years of Republican leadership in the White House, Rosemary Ruether observed, "'Pro-family' has become the rallying cry of a coalition of conservative movements that can be expected to have a significant effect upon the current election." "They did. And American conflict over the family has continued to influence the political scene. In 1992 the Bush campaign tried to rally support behind so-called "traditional family values" and failed. Many people, it seemed, were ready to stake their claims on Hilary Rodham and Bill Clinton. Perhaps the sort of relationship that they modeled, despite the apparent ambiguities, was more real to more people than every before.

Of greater interest to me than politıcal commentary is a theological analysis of the debate in light of Ruether's very interesting concluding recommendation. She states the "imperative need vigorously to contest the claims of the New Right to represent the interest of the 'famly.',"2 Feminists and other progressives would do well to keep the issue of the family in our own camp, she argues, and not allow conservatives to accuse us of being against the values of families and children. In particular, "Spokespersons for reform need to make it clear that they have a more accurate analysis of the crises of the family than the right, an analysis that speaks more meaningfully to the real experience of ordinary people." She concludes, "The home is too important a place for all of us to give it away to the right.",3

Among Christian feminist theologians, the discussion on the family has advanced beyond what Ruether proposes. In fact, feminist theologians have

The Journal of Pastoral Care, Spring 1995, Vol. 49, No. 4

${ }^{1}$ Rosemary Ruether, "Politics and the Family Recapturing a Lost Issue," Christianity and Crisis, 1980, Vol 40, p 261

${ }^{2} I b \imath d$, p 264 Emphasis added

${ }^{3}$ Ibrd , p 266 
been talking about family values of a different sort for longer than many people would like to suppose. At the same time, it hardly seems that anyone has heard or listened. In too many cases, extremely helpful feminist theologians' reconstructions of families, work, love, and justice have simply not reached ministers and congregations, much less families and the workplace. Often pastors and pastoral counselors assume alternative values of mutuality and gender justice, but fail to claim and articulate them forthrightly as alternative theological family values. This article attempts to work against these tendencies. I want to expand on the analysis of the dilemmas of families that Ruether hastily sketches at the conclusion of her essay and I want to consider a few appropriate responses from those in pastoral care. The better question, in my estimation, is not who is pro-family, but which pro-family values one adopts and how one adopts them.

\section{The Culture War and the American Family}

Although Ruether advocates a more authentic analysis of the problems than that propounded by the religious right, her own analysis is all too brief.

Most women know that it is not feminism but rising inflation that is creating the need for the two-income family Once in the workplace, the woman not only deals with problems of undeveloped skills, economic discrimination and sexual harassment, but she also runs a rat race of tryıng to coordinate the tasks of family with those of the workplace in a system that has set the two in opposition to each other

This is a good thumbnail sketch, but it is not enough. ${ }^{4}$ In an essay, "The Church and the Family: An Ethical Task," written a few years after Ruether's essay, Margaret Farley makes an obvious point that nonetheless deserves belaboring: "If the Christian community's theological and ethical reflection is to address effectively the problems and needs of the family, much depends on the accuracy of the analyses of these problems and needs '5 In a parallel way, the adequacy of pastoral responses to people and families who seek religious care also depends on how those in pastoral care understand the problems. Is the family in "decline," or are people in families of many shapes and dynamics trying to contend with social, cultural, and economic forces that fall far beyond their current sphere of influence?

People at opposite ends of the spectrum on family values must contend with at least two significant trends in the last twenty years. One is the dramatic increase in our-of-wedlock births, particularly teen pregnancy, and the second is the dramatic rise in divorce. These trends have contributed to what one source calls a "remarkable phenomenon: One out of four children under the age 18 in the United States now live in single-parent families." 6 If there is an additional notable change in family structure, it is the increasing numbers of women in paid employment.

What people make of these trends, however, and even which trend people

\footnotetext{
"Ibrd This is not to say that Ruether has not expanded this analysis helpfully elsewhere See, for example, her essay "An Unrealızed Revolution Searching Scripture for a Model of Famly," Chrstianity and Crsses, 1983 (Oct), pp 399-404

"Margaret Farley, "The Church and the Family An Ethical Task," Honzons, 1983, Vol 10, No $1, \mathrm{p} 51$

'Peter L Benson and Eugene C Roehlkepartain, “Single-Parent Families," Source, 1993, Vol IX, No 2 , $\mathrm{p} 1$
} 
choose as important, diverge greatly. Two distinct, often competing, uses of family-related statistics, social science, history, and theology have arisen. One particular approach likes to take these "large-scale statistics and aggregate sociological trends,"' and lay the problem at the doorstep of THE FAMILY. These are "domestic problems," argues Barbara Defoe Whitehead, "closely connected to family breakup." $"$ The family predicament in this view is centered in the declining well-being of children and the rising individualism of adults.

There is a tone in Whitehead and much of the "family decline" literature that implicitly and sometimes explicitly blames parents for abandoning the home and children in a self-centered pursuit of their own happiness in the workplace and otherwise. Whitehead announces, "What had once been regarded as hostile to children's best interests" in the 1950s is "now considered essential to adults' happiness." The "social metric," she claims, has shifted "from child well-being to adult well-being." She goes on to scold people for shamelessly failing to realize "what contributes to a parent's happiness may detract from a child's happiness." 9

Because Whitehead uses the quasi-inclusive term parents, it is hard to tell here whether she is talking to mothers, fathers, or both. But since paternal behavior has not changed that much in the last century, or perhaps not as much as maternal behavior, it is hard not to hear this as a message directed at women. Even if she is talking to fathers and not scolding mothers specifically, it is true that when people declare something wrong with family life, it is still primarily women who take these kinds of declarations most seriously and most personally.

Equally compelling statistics can be rallied-and this is where I locate myself-to support a contrasting contention that most women, and some men, are doing more than ever before to keep families afloat and to care for others besides themselves. This approach tends to use experience-near datacase studies, qualitative interviews, detailed ethnographic research on single families, and autobiographical reflections. ${ }^{10}$ It finds that women of all colors and classes, and some men, continue to carry out an enormous amount of indispensable, unremunerated caring labor which at once undergirds human life and is peripheral to it as dominant culture has defined it, and therefore without values. Arlie Hochschild's The Second Shift takes the major studies on time use done in the 1960s and 1970s, and discovers that "women worked roughly fifteen hours longer each week than men. Over a year, they worked an extra month of twenty-four-hour days a years. "'11 Mothers in two-income families are much more likely than fathers to make child-care arrangements, take time off from work than fathers to make child-care arrangements, take time off from work when children need attention, and compromise their jobs and themselves for the sake of children. In general, those of either sex who choose to engage in domestic labor are placed at a clear disadvantage in American society at large.

\footnotetext{
'Pamela Couture, "Single Parents and Poverty A Challenge to Pastoral Theological Method," in Pastoral Care in Social Context (Nashville, TN Abingdon Press, forthcoming)

"Barbara Defoe Whitehead, "Dan Quayle Was Right," Atlantic Monthly, Aprll 1993, p 48

${ }^{9} I b \imath d$, PP 52,58

${ }^{10}$ Couture, op ctt

${ }^{11}$ Arlie Hochschild, with Anne Machung, The Second Shift Working Parents and the Revolution at Home (New York, NY Vikıng, 1989), pp 3-4
} 
People like Whitehead tend to ignore other statistics. Although not the sole solution to rising divorce rates, some research indicates that fully sharing child-rearing duties is the "single best predictor of happiness in a dual-career family." 12 Women who regard the division of household tasks between husband and wife as unfair are "much more likely to report trouble in their marriage" even though most men do not perceive the problem. ${ }^{13}$ The more hours a woman works, the more likely she is to report trouble if she finds the division of household labor unfair. Yet the front-page news continues to report that the "new man [is no more] willing to pick up a broom than his father." 14 It should be no surprise that studies indicate that when women marry their overall emotional and physical health tends to worsen, while "marriage benefits men's health." 15 At the same time, other studies have confirmed that, besides obtaining economic security, "working women . . . are less lonely, less anxious and worried, have fewer substance abuse problems, feel more worthy as human beings, and report greater marital satisfaction.,"16

Not only are many women and some men doing more work to maintain an adequate domestic and economic life, the United States government has done even less on some important scores. Working women who wish to have children have had no national statutory maternity benefits-no health care for themselves and their infants, no job-protected leave, no income replacement. In Sweden, England, Italy, France, and one hundred and thirteen other industrial and developing nations, women, and in some cases men, receive up to eighteen months paid leave, two years unpaid leave, job protection, fringe benefits, even credit toward seniority. Throughout the 1980s and annually from 1988 to 1992 , the women's policy community and their allies tried repeatedly to pass the Family and Medical Leave Act (FMLA). Approved during the first month of the Clinton administration, it grants twelve weeks unpaid leave to businesses that employ 50 or more employees. ${ }^{17}$ Yet, according to a Bureau of National Affairs study, about 77 percent of women in low-paying, nonprofessional jobs would likely not be able to take time off without pay. Disproportionate numbers of women work for smaller firms, and women make up more than two-thirds of the part-time and temporary work force not entirely covered by the FMLA.

In addition, the United States is alone among eighteen democracies in failing to offer a family allowance or government subsidy per child. In 1948 the United States offered a personal tax exemption of $\$ 600$, close to the cost of raising a baby in its first year at that time. The relative financial incentive this represented to raise children has shrunk over time. The actual value of today's personal exemption of $\$ 2,000$ is far less than it was in 1948 , according

\footnotetext{
${ }^{12} I b \imath d, \mathrm{p} 41$

${ }^{13}$ Larry L Bumpass, "What's Happening to the Family? Interactions Between Demographic and Institutional Change," Demography, Vol 27, No 4, p 491

14“'Times Change, Many Job Attitudes Don't,"' Chicago Tribune, September 3, 1993 Front page

${ }^{15}$ Francesca M Cancian, Love in Amenca Gender and Self-Development (Cambridge Cambridge University Press, 1987), p 88

${ }^{16}$ Veronica F Nieva, "Work and Family Linkages," in Laurie Larwood, Ann H Stromberg, and Barbara Gutek (Eds), Women and Work An Annual Revtew, vol 1 (Beverly Hulls, CA Sage, 1985), pp 162-90, cited by Rosemary Curran Barciauskaas and Debra Berry Hull, Loving and Work Reweaving Women's Public and Private Lives (Bloomington, IN Meyer-Stone Books, 1989), P 162

${ }^{17}$ Lise Vogel, Mothers on the Job Maternity Policy in the $U S$ Workplace (New Brunswick, NJ Rutgers Unversity Press, 1993)
} 
to Elaine Ciulla Kamarck and William Galston with the Progressive Policy Institute. Simply adjusting for inflation would put the 1948 exemption near $\$ 3,000$ and estimate of the cost of raising an infant in the first year in 1990 have risen to $\$ 6,000-\$ 7,500 .^{18}$

From this perspective, therefore, the family predicament is not centered so much in the declining well-being of children and the rising individualism of adults, although these are related concerns, but in the internal struggles to democratize the family and the external struggles to create social and economic policy that supports democratized families and the care of dependents-not just children-but all those with special needs. This analysis shifts the focus from THE FAMILY to democratic relationships in families and, ultimately, to family-related public policy adequate to such relationships. At the center of family turmoil are not problems with families per se-individualism, divorce, single-mothers, pregnant teens, neglected or problem children-as difficult as such phenomena are. At the heart of family turmoil is the very, very difficult problem of establishing, much less maintaining, genuinely democratic family forms and dynamics.

In this second interpretation of current family dilemmas, there is a tendency to blame men for failing to do enough and a tendency to blame inadequate public policies that fail to provide even the smallest incentive to encourage people to shoulder the responsibilities of maintaining strong families. Condescending attributions of blame on the part of any party do not get us very far. I am increasingly aware of the pejorative, moralistic misuse of terms like decline and even crisis. Those who feel slightly responsible for the problems or are deeply involved in them first-hand are less likely to use these terms than those who seem to hold others at fault and view the problems from some kind of political, scholarly, generational, or even gender distance.

Yet blame is certainly a part of the culture war that is occurring between various factions in our country. When James Hunter uses this term, he means a conflict that is not simply over public policies or the politics of such issues as abortion, homosexuality, values in schools, and sexual harassment, but is a debate over "how we as Americans will order our lives together." 19 It is a debate over some very basic nonnegotiable moral convictions and deeply embedded worldviews. And the family is, in Hunter's words, "the most conspicuous field of conflict." In fact, the way people answer the most intimate questions of how authority, power, responsibility, obligation, and sexuality are ordered in family life may be pivotal to the way the other battles will be determined.

If the debate is about moral and cultural worldviews as much as it is about the particulars of the issues at hand, those who form the visions and the norms, including theologians and clergy, help determine the outcome. Moreover, congregations and their leaders often have close connection with the most intimate moments in people's lives over the human life cycle. For better or for worse, clergy stand in a critical place to influence people over these intimate questions. Sometimes, as Ruether demonstrates, this has been for the worse. Clergy most willing to use this influence have most often been those on the right, eager to maintain a nonegalitarian status quo.

\footnotetext{
${ }^{18}$ Elaine Ciulla Kamarck and Willıam A Galston, Putting Children First A Progressive Family Policy for the 1990s (Washington, DC Progressive Policy Institute, 1990), pp 22-23

${ }^{19}$ James Davison Hunter, Culture Wars The Struggle to Define America (New York, NY Basic Books, 1991), p 266
} 


\section{Alternative Pro-Family Values}

If mainline/oldline Christianity and Christian feminists do not get clearer about alternative egalitarian family and work values, then many people will not have a good defense against the nostalgia for the "way things never were," as Stephanie Coontz's book title puts it. Feminist theologians have not always been clear about alternative values. This is true in the essay by Ruether. Although she advocates providing an analysis capable of countering the scapegoating tendencies, of the analyses of the New Right, her own analysis of the dilemmas is only about two lines, and her solution an added paragraph. The latter lacks the ethical, theological development it needs and which she does so well elsewhere. She is slightly romantic about the possibilities of social reconstruction without this development:

Working mothers not only need good inexpensive day care, they need a restructured social order that locates home, school, nursery and work in some more coherent relationship to each other. They need a society that is rebuilding the organic supports around these realities of daily life, instead of asking the working man and woman to hold together this fragmented life through some monumental effort of self-extension. Most of all, women need a society that promotes support for women and children by making it possible for fathers to be equal participants in the rearing of children and the building of homes. ${ }^{20}$

These are critical social changes. But they slightly sidestep the theological and moral considerations that are equally requisite.

Contrary to Hunter's subtly biased depiction of the culture war, those on the right and those on the left are not equally well-organized. Although Hunter claims that at the heart of the culture war is a rearrangement in alliances among those who have not been traditionally allied (e.g., the Catholic pro-life with Protestant fundamentalists), this realignment is rather one-sided. Those on the right have been a great deal more intentional about organizing around family issues than those on the left. In many cases, those on the right have been quite willing to override differences for the sake of acquiring national power on political issues, while those on the left have been busy trying to understand differences and particularily for the sake of greater authenticity and integrity. In a way, the left is in greater disarray by political, cultural, and moral intention.

There is not a single feminist theological position or voice on the family. At least three rough groups need representation: white religious feminists like Ruether, Farley, and more recently, Christine Gudorf, Sally Purvis, Pam Couture, and others; the more recent contributions of womanist theologians such as Deloras Williams, Bonnie Thorton Dill, and other people of color like Mercy Amba Oduyoye; and the recent contributions of conservative and evangelical feminists like Mary Stewart Van Leeuwen. At the same time, I believe, among the significant contributions of these different voices at least one common theme emerges: the priority of egalitarian relationships of justice and mutuality in the family.

In Also a Mother: Work and Family as Theological Dilemma, I attempt to develop this theme and name some of the theological issues at stake. The book emerged, as I say in the introduction, in "the eye of [the] storm over my attention" as a seminary professor and a mother of three sons, eight,

${ }^{20}$ Ruether, “Politics and the Family," p. 266. 
five, and three years old. When I try to describe the daily conflicts in the academic context, it can tend to sound trite, although it very seldom does in the many personal conversations I have had with many other employed parents. I have asked myself: How can the twist of the heart and the real burdens of care be described and understood without sounding sentimental, fretful, and less than serious? Why try? Why even risk writing a book entitled Also a Mother? Very briefly, here are four of the many reasons and they become important theses in the book: (1) the need to dispel the deadly silence that surrounds what it means that mostly women mother, a silence particularly characteristic of the academy; (2) the need to correct the tendency either to trivialize on the one hand or to romanticize on the other what it really takes to raise a child in a complex, technological, post-modern society; (3) the need to expose and correct the inadequacy of psychological theories of human fulfillment, economic theories of work, and theological theories of love and vocation that emphasize productivity, discount the entire structures of women's caring labor that undergird the economy, and continue to promote selfsacrifice as an ultimate value; and finally (4) a hunch that the burdens about which I speak are not mine alone. Many women and some men face similar burdens with fewer material and relational resources than I do.

These propositions necessitate nothing less than a radical transformation in religious sanctions about family and work for men and women. Christian ideals of motherly self-sacrifice and fatherly hard work, as they have been interpreted by church tradition and promoted in society at large, not only fail the lives of many people today, they misrepresent both the intent of human creation and the promise of the Christian gospel itself. A revision of the theological ideals of love, work, and vocation is critical to moving beyond the nostalgia for "family values" that is too often a disguised desire to reinstitute male dominance and female self-sacrifice.

Despite the sexual subordination in both New Testament and Hebrew scriptures, despite the patriarchal character of the ancient Israel and the Roman and Hellenistic cultures in which Christianity arose, and despite the ways in which the Christian tradition has perpetuated ideals of male dominance in the centuries since, current scholarship continues to confirm important streams of thought at variance with these assumptions. ${ }^{21}$ Just, democratic, egalitarian relationships of radical mutuality in families and elsewhere are not only the intent of human creation, but the promise of the Christian gospel itself. Over against social convention Jesus kept egalitarian premises at the core of the breaking in of the kingdom. Paul follows suit, even as he struggles and sometimes fails to realize the ideal of equality and discipleship in some of his words to the actual communities he was founding. His absolute insistence on the silence of women in the church in I Cor. 14:3435 contradicts the radical inclusivity of his message elsewhere. This passage has been explained as a concession to the prevailing values of his time or even as the imposition and addition of someone else's words. In either case, it is a compromise, as is I Tim., that his other claims undercut. Authoritative moral norms about women, divorce, and other family-related concerns are reinterpreted by Paul in light of a greater moral criterion-the existence and preservation of community in the midst of the proclamation of the reign of

${ }^{21}$ The following two paragraphs are based on Chapter 6 of Also a Mother Work and Families as Theological Dilemma (Nashville, TN Abingdon Press, 1994) 
God. He puts at the center of a life in Christ a revolutionary creed, "For as many of you as were baptized into Christ have put on Christ. There is neither Jew nor Greek, there is neither slave nor free, there is neither male nor female; for you are all one in Christ"' (Gal. 3:28).

Remnants of egalitarian themes that undercut and challenge I Tim. run even further back in scriptural traditions. The same creation stories (Gen. 13) that the author of I Tim. uses to justify women's subordination can serve instead as evidence of the equality of women and men. Female and maternal subjugation and silence is not divinely ordained and revealed in the Hebrew scriptures any more than in the New Testament. To the contrary, the creation stories in Gen. 1 and 2 portray as normative an equal partnership of women and men in dominion and in fruitful propagation of the species. In Gen. 3 we find that sexual inequality perpetuates sin rather than fulfills some divine decree. Women have no lesser place in creation and no greater culpability in perpetuating human corruption than men.

Whether or not there is agreement about the problems of families or with this very brief biblical, theological exposition, it is hard to deny the lived experiences of families. If it is primarily or partly within the family that children first come to have a sense of themselves and of a sense of human and human-divine relationship that is foundational to moral and spiritual development, then it makes all the difference in the world whether this experience is one of unequal altruism and one-sided self-sacrifice on the part of women and mothers or of justice, mutuality, and reciprocity. Susan Moller Okin states this powerfully:

What is a child of either sex to learn about fairness in the average household with two full-time working parents, where the mother does, at the very least, twice as much family work as the father? What is a child to learn about the value of nurturing and domestic work in a home with a traditional division of labor in which the father either subtly or not so subtly uses the fact that he is the wage earner to "pull rank" on or to abuse his wife? What is a child to learn about responsibility for others in a family in which, after many years of arranging for life around the needs of her husband and children, a woman is faced with having to provide for herself and her children but is totally illequipped for the task by the life she agreed to lead, has led, and expected to go on leading? ${ }^{22}$

What will a child learn? A child will learn a distorted sense of justice, trust, equality, and vulnerability that requires sacrifices of women that are not required of men. To Okin, I must add, the family is by no means the only place where injustice is learned and inordinate sacrifice is required, but it is among the primary places. And families alone cannot institute equality in the tasks of caring labor when work structures, social institutions, and dominant ideology all work against it. But if we want to transform and liberate, if we want to set people free as we have been called to do by our creation and by Christ, reclaiming space in the contested terrain of THE FAMILY is critical.

\section{Pastoral Care: Reclaiming Space in Contested Terrain}

This final section deserves more space than I can give it here. But I want to

${ }^{22}$ Susan Moller Okın, Justzce, Gender, and the Famıly (New York, NY: Basic Books, 1989), pp. 2324. 
draw on a grid proposed in the final chapter of Also a Mother to suggest the kind of reflection and conversation that must begin to take shape both in the pastoral office and among people in congregations. Congregations have at least three distinct, but interrelated roles in addressing work and family as a creative theological dilemma: (1) a descriptive or pastoral role (this is how life is these days); (2) a normative or prophetic role (this is how life should be); and (3) a programmatic or proclaiming role (here are a few ways to get there). Although I discuss these three tasks separately and largely in terms of congregational activity, each task is integrally related, and all three are tasks that pastoral caregivers, counselors, and therapists must also begin to comprehend and implement.

In many cases, these three tasks or spheres of activity call for a much more directive style of intervention in people's lives than has been the typical nondirective counseling style advocated by those in pastoral and practical theology in the last several decades. In the conflicts over American family models, structures, and dynamics pastoral counselors cannot just sit back and listen. Although prescribing ideals before adequately understanding the problems is a peril to be avoided at almost all costs, mainline/oldline, reformist, and progressive pastoral counselors have a crucial obligation to forge a few bottom-line normative judgments on lifestyles and at least to get as clear as possible about their position on critical family issues.

When it comes to questions about work, love, and intimacy, psychology has operated as a quasi-religious, culture-forming body of knowledge. When people turn somewhere for help in solving dilemmas of work and family, it is not so much to church and synagogue, not to sacred scriptures and theologians, but more often to the self-help bookshelves, popular talk shows, and therapeutic interventions that the modern discipline of psychology has spawned. People are talking about dire family conflicts within the sanctuary of personal therapy, whether pastoral therapy or some other kind. This is one place where the most intimate family issues are not taboo and where people very often find convincing and helpful answers.

In many cases, this is a good thing. But, I would argue, one of the first tasks of the pastoral counselor is to try to return some of this intimate conversation to the congregation where it also belongs. Talking in therapy was never intended as a replacement for public discussion, but in many cases, that has indeed been the case. By providing a "holding environment" separate from the congregation-something absolutely necessary because these issues were not being dealt with to any extent in congregations and perhaps could not be dealt with there-pastoral counseling has effectively robbed many congregations of some of the most highly-charged, emotionally lifegiving material that the congregation actually needs in order to care for itself and the people in its spheres.

By saying "return this intimate conversation to the congregation," I mean encouraging public discussion of some of the problems which have been heretofore taboo for many congregations. In a word, pastoral counselors should encourage those whom they counsel to return to their congregations either to speak up about or to ask for discussion of some of the intimate dilemmas about which they seek therapy. Pastoral counselors have an obligation to disturb the "conspiracy of silence," in Janet Fishburn's words, that enshrouds what happens in the family lives and to break the unwritten rules about what can and cannot be discussed during "Joys and Concerns" in 
many typical small church worship services. ${ }^{23}$

This kind of conversation is bound to be conflict-filled and challenging for most congregations used to hiding family tensions. Pastoral skills of good listening and mediating will be in high demand. Pastoral counselors ought to share what they have learned so well in individual and family therapy settings with the wider congregational life-how to create and sustain a safe, dependable, predictable, trustworthy, sustaining holding environment or space that allows open communication about the current gender, familial, relational, marital, intergenerational, and vocational strife of everyday life for nearly everyone. Such communication will require a level of engagement, conflict, and empathy that many mainline/oldline congregations and families are bound to find most trying. But, in many ways, what better place to have such a conversation than where people of many generations sit side by side in an institution which is situated between private and public spheres of life, where there are opportunities for informal gatherings of many shapes and sizes, and where people have moral traditions and scriptures to call upon as proven resources and as new visions?

Exploring "how life is these days" inevitably raise questions about how it should be. By recent definition, pastoral counselors provide a space where moral imperatives that normally operate in congregational settings can be relaxed and temporarily suspended for the sake of further understanding. Yet if a counselor believes a democratic relationship better than a hierarchical, dominating, oppressive, or exploitative one and believes that position to be grounded within religious tradition, that counselor has a relative obligation to claim and articulate this position. I say "relative" because I am not arguing that the counselor force or even subtly convince a counselee to adopt this position. I am arguing that where a counselor stands on the pivotal issue of gender justice has a necessary and unavoidable bearing on the outcome of the therapy, whether articulated or not. At this particular historical moment, it is better to articulate one's position. Although I am not advocating religious moralism about egalitarianism, I am well aware that a little moralism in this direction will still not do much to alter centuries lived under the moralisms of domination and submission.

Like it or not, those who seek counseling are deliberating over moral values and visions intimately related to how they enact their family lives. In this second sphere of activity, pastoral counselors can participate in challenging distorted definitions of the "good mother" that equate goodness with selfsacrifice and definitions of the conventional family that rely so heavily on the domestic labors and self-giving of women. They can play an important role in supporting the virtues of "good enough" fathers and "good enough" families who share the burdens between men and women as justly as possible and of "good enough" mothers who give of themselves without losing themselves. Moreover, this kind of stance cannot be adopted wholeheartedly without also questioning the impersonal organization of almost all work environments and the materialistic, production-oriented economic norms that put products and profits before persons.

Finally, as a third area of need, pastoral counselors should not be so afraid to talk in greater detail about what democratic relationships between

${ }^{23}$ Janet Fishburn, Confronting the Idolatry of Family A New Vision of the Household of God (Nashville, TN Abingdon Press, 1991), p 141 
men and women actually look like in real life. Many people are hungry for stories by which to live. They want to know how to share domestic and economic labors, particularly in a society that typically forbids such equal sharing. A pastoral counselor should not withhold any viable ideas about the actual logistics of redistributing household chores, a demanding and timeconsuming task for many couples. How can people change the division of labor inherent to conventional gender role definitions? What have people tried? What works and what doesn't? How can people change the division of domestic labors in the congregation itself which continues to presume that women will run the Sunday School, coffee hour, nursery, funeral meals, and assume positions of leadership both in the congregation and in the work world? What will it take to teach men to tend to the chores of relationships, domesticity, and children, and as important, to reclaim the values of caring labor for both men and women in a society driven by the marketplace that devalues the taking care of children, elevates material productivity, places in jeopardy those in significant caregiving toles, primarily women, and forbids men serious concern over friends, children, family, and domicile? In this case, what is important is not so much where a counselor stands on the issue of gender justice, but what do counselors themselves $d o$ in their own lives?

If there is one common theme that runs through the lives of many diverse people, it is the speed-up and the strife over determining domestic and economic responsibilities amidst the pressures of a fast-paced, status-conscious, technological society. The public-private split whereby men work and women love has been challenged, but not many helpful new ideals and forms have replaced old structures. As Judith Stacy observes, "we are living . . . through a transitional and contested period of family history, a period after the modern family order, but before what we cannot foretell." We have come to a stage "when belief in a logical progression of stages breaks down." 24

A long-standing, deeply embedded division of domestic labor has not changed, despite all the other gender changes. This domestic division continues to isolate husbands and wives from each other, to exclude fathers from family attachments, and to restrict mothers from personal and public achievements. This threefold internal "divorce" is often a prelude to an official divorce and it is at the heart of problems of many families today. ${ }^{25} \mathrm{Just}$ as some women have begun to claim some of the fruits of self-fulfillment, everyone, from politicians to scholars and studies like Habits of the Heart, have decried the dangers of rampant individualism and the decline of communal commitments to the common good and family values. ${ }^{26}$ While these judgments may be partially valid, we have to wonder about their accuracy in terms of the course of the lives of women and the lives of other oppressed groups in our society. While the individualistic spirit of much of American society does pose certain problems, one has to wonder how much of the uproar over individualism and the outcry of "family values" is about the collapse

\footnotetext{
${ }^{24}$ Judith Stacy, Brave New Families Stornes of Domestic Upheavel in Late Twentieth Century Amenca (New York, NY Basıc Books, 1990), p 18

${ }^{25}$ Frank F Furstenberg, Jr and Andrew Cherlin, Divided Families What Happens to Children when Parents Part (Cambridge, MA Harvard University Press, 19910, pp 28-30, 46-49

${ }^{26}$ Robert N Bellah, Richard Madsen, William M Sullivan, Ann Swindler, and Steven M Tipton, Habits of the Heart Individualism and Commitment in American Life (Berkeley, CA University of Calıfornıa Press, 1985)
} 
of a public-private dichotomy as women and minorities cross taboo dividing lines.

Whitehaed and others juxtapose and present as usually exclusive options a child well-being and a parent's well-being. By contrast, I believe that we do not get very far by pitting these two happinesses-the mother's (or father's) and a child's-against each other. A parent's parental love of a child and a parent's commitment to a marriage has everything and nothing to do with child welfare. A singular mono-causal link between adult happiness and child unhappiness cannot be drawn. Alterations in family structure do not, in and of themselves, determine human well-being. Family life is more complicated than that. From this perspective, it makes more sense to presume that if we strive to increase the well-being of all parents we will help increase the well-being of children. We cannot help children without helping mothers and fathers. 2

\section{Blanton - Peale}

\section{Intensive-Extensive Residencies in Pastoral Psychotherapy, Psychotherapy, and Marriage and Family Therapy}

For over 50 years the Institutes of Religion and Health has fostered the healthy marriage of psychotherapeutic insight and religious wisdom, seeking to plumb the depths of both in order to help persons participate more fully in the healing process.

To those willing to undergo rigorous preparation, we offer programs that enable residents to master psychodynamic theory while being deeply immersed in thoroughly supervised clinical practice. Each person's unique heritage-personal, familial, religious, and ethnic-is honored as an essential ingredient in the training process which includes an intensive personal therapeutic journey.

For further information, please call 212-725-7850 or (800) 225-5603. Or write:

James C. Wyrtzen, D.Min., Director of Training BLANTON-PEALE GRADUATE INSTITUTE

3 West 29th Street, New York, NY 10001 